\title{
IbM KEPADA IBU-IBU PKK RT 8 DAN RT 10 DI DESA GROBOGAN KECAMATAN JIWAN MELALUI PEMANFAATAN TAS KRESEK BEKAS MENJADI PRODUK RAJUT SEBAGAI KERAJINAN TANGAN RAMAH
}

\author{
Nuri Ati Ningsih ${ }^{1)}$, Asri Musandi Waraulia ${ }^{2)}$ \\ ${ }^{1)}$ FPMIPA, IKIP PGRI MADIUN \\ email: nuri_basir@yahoo.com \\ email: asrimusandi@yahoo.com
}

\begin{abstract}
This activities conducted to overcome the problem of rubbish produced by the environment around. In this case, plastics as the main focus to be hadlled in the form of handicraff, such as bag, wallet, pencil case, and handphone case. Some purposes will be gained, they are (1) decreasing the number of rubbish produced by environment, especially plastics bag; (2) helping the housewives to increase their income by making some handicraff from plastics; (3) supporting the envirnment to be a go green area. This activities have been done in a routine workshops attended by some housewives in two group activities. The result of activities are; (1) some products from plastics , (2) positif activities done by some housewives, and (3) clean environtment/go green area.
\end{abstract}

Keywords: rubbish, plastics bag, housewife, and go green area.

\section{PENDAHULUAN}

Bertambahnya jumlah sampah, utamanya sampah plastik, akan berdampak negatif kepada lingkungan. Sampah dalam bentuk plastik cukup susah diuraikan. Penelitian menunjukkan bahwa sampah plastik akan terurai dalam jangka waktu 50 juta tahun, sehingga sampah menjadi masalah serius. Hal ini menjadi masalah besar tidak hanya dikota-kota besar yang tidak memiliki pengelolaan sampah yang baik, tetapi juga didesa-desa. Salah satu sampah yang menjadi masalah serius adalah sampah plastik. Sementara, penanganan sampah plastik di Indonesia hingga kini dinilai masih sebatas wacana. Penilaian tersebut disampaikan Direktur Yayasan Wisnu Made Suarnatha pada VOA. Tidak terdapat mekanisme implementasi yang jelas tentang bagaimana penyelesaian terhadap sampah plastik. Begitu juga aturan yang ada, seperti Undang-Undang Nomor 18 Tahun 2008 tentang pengelolaan sampah tidak terimplementasi secara optimal. Selain itu aturan hukum yang ada selalu hanya diwajibkan bagi masyarakat, tetapi masyarakat belum bahkan tidak menyadari secara jelas tentang aturan tersebut. Implementasi aturan terhadap penanganan sampah plastik semakin tidak jelas karena tidak disertai penyediaan infrastruktur pendukung yang memadai.

Dibutuhkan penanganan yang serius agar sampah plastik ini dapat terkendali. Dibutuhkan upaya penanganan serius melalui peran serta pemerintah, swasta, dan masyarakat serta para stakeholder dalam bekerja sama menyelesaikan masalah ini. Dibutuhkan kepekaan, kejelian, ketekunan, kecerdasan serta kerjasama yang maksimal untuk menangani limbah ini. Ada banyak cara untuk melestarikan lingkungan kita, namun untuk memulainya bisa kita lakukan cukup dengan langkah-langkah kecil dulu yang ada disekitar kita sehingga bisa terwujud. Penanganan serius dapat dimulai dari lingkungan kecil, lingkungan rumah tangga. Ibu-ibu dalam sebuah masyarakat memiliki peranan penting dalam mengentas kebiasaan buruk semua warga masyarakat. Namun, bila kebiasaan itu sudah melekat, maka perlu adanya kecerdikan dalam memanfaatkan sampah plastik menjadi barang yang berguna, bahkan berdaya jual.

Berdasarkan perkembangan ilmu pengetahuan dan teknologi, sudah seharusnya ada suatu cara untuk mengolah atau memanfaatkan limbah tas plastik kresek bekas ini. Dalam pengolahannya, kita dapat memikirkan aspek ekonomisnya pula, agar kita terpicu untuk terus me - recycle alias mendaur ulang limbah tas plastik kresek bekas untuk menyelamatkan eksistensi kebersihan bumi tercinta ini. Selain menjadi isu kritis saat ini, kita harus mampu memanfaatkan isu global warming untuk dapat menjadi peluang usaha dengan membekali keterampilan pengolahannya pada ibu-ibu rumah tangga, sehingga kaum ibu ini mempunyai bekal dan semangat untuk mengelolanya. Berangkat dari niat ikut terlibat menyelamatkan lingkungan ini, sisi positif lainnya adalah menjadi lahan bisnis yang menguntungkan serta membangun kemandirian dalam hal finansial. Segala sesuatu yang besar, dimulai dari hal yang kecil.

Program ini akan dilaksanakan 
bekerjasama dengan kelompok masyarakat yang bernaung dalam perkumpulan ibu-ibu RT. Ada 2 kelompok ibu-ibu PKK yang akan menjadi mitra, yaitu ibu-ibu RT 8 RW 4 dan RT 10 RW 5 Desa Grobogan Kecamatan Jiwan Kabupaten
Madiun. Pemilihan mitra ini didasarkan pada observasi awal yang telah kami lakukan. Observasi awal ini menghasilkan informasi sebagaimana tercantum dalam tabel berikut ini.

Tabel : I Data mitra

\begin{tabular}{|c|c|c|c|}
\hline No & Jenis Data & RT 8 & RT 10 \\
\hline 1 & Jumlah KK & 32 & 34 \\
\hline 2 & Jumlah Ibu-ibu Tangga & 35 & 40 \\
\hline \multirow[t]{6}{*}{3} & Usia Ibu Rumah Tangga & & \\
\hline & 20 thn -30 thn & 4 & 7 \\
\hline & 30 thn -40 thn & 11 & 12 \\
\hline & 40 thn -50 thn & 9 & 6 \\
\hline & 50 thn -60 thn & 7 & 9 \\
\hline & 60 thn -70 thn & 4 & 6 \\
\hline \multirow[t]{7}{*}{4} & Tingkat Pendidikan Ibu Rumah Tangga & & \\
\hline & Tidak Sekolah & 2 & 7 \\
\hline & SD & 12 & 18 \\
\hline & SMP & 9 & 7 \\
\hline & SMA & 15 & 8 \\
\hline & Akademi & - & - \\
\hline & Perguruan Tinggi & 1 & - \\
\hline \multirow[t]{7}{*}{5} & Pekerjaan Ibu Rumah Tangga & & \\
\hline & Tidak bekerja & 13 & 16 \\
\hline & Buruh Tani & 14 & 19 \\
\hline & Petani & 3 & 2 \\
\hline & Wiraswasta & 2 & 3 \\
\hline & Swasta & 1 & - \\
\hline & Pegawai Negeri & 1 & - \\
\hline
\end{tabular}

Berdasarkan data tersebut dapat diuraikan bahwa profesi mayoritas penduduk RT 8 dan RT 10 adalah buruh tani. Hal ini terjadi karena tempat program ini akan dilangsungkan adalah di daerah pedesaan yang mayoritas penduduknya adalah bertani. Buruh tani adalah suatu profesi yang dilakukan dengan menjual jasa pada seorang petani pada waktu menggarap lahan dan memanen hasilnya. Berdasarkan waktu tersebut bisa di katakan jangka waktu para buruh tani ini bekerja dan mendapatkan hasil secara pasti adalah sekitar 4 minggu. Dua minggu bekerja untuk masa panen sehingga upah berupa gabah dengan sistem bagi hasil. Biasanya menganut sistem 10:1. Artinya Kalau buruh tani itu mendapat $10 \mathrm{~kg}$ gabah/padi maka akan mendapat upah $1 \mathrm{~kg}$ gabah. Waktu panen ini mereka akan bekerja siang malam untuk mendapatkan bahan makan pokok selama 4 bulan. Sedangkan pada waktu musim tanam sistem yang dipakai adalah sistem upah. Dalam satu hari buruh tani laki-laki akan mendapat upah Rp. 40.000,- sedangkan yang perempuan mendapat upah Rp. 30.000,-. Masa tanam dan panenbiasanya terjadi dalam waktu empat bulan. Praktis mereka bekerja sekitar 3 bulan untuk hidup satu tahun. Sementara untuk kaum lelaki kalau ada tawaran bekerja sebagai kuli bangunan, mereka akan mendapatkan hasil tambahan dan untuk kaum ibu-ibu otomatis mereka tidak akan mendapatkan hasil tambahan. Berdasarkan kondisi perekonomian yang dialami serta waktu luang yang ada, maka kami berinisiatif untuk membekali ibu-ibu rumah tangga tersebut dengan ketrampilan khusus dengan menggunakan bahan dasar yang murah dan mudah didapat karena secara tidak langsung mereka mendapatkannya setiap hari. Diharapkan ketrampilan ini akan berdampak positif pada kehidupan mereka karena mereka 
akan mendapatkan ilmu baru, income tambahan serta tertanganinya limbah rumah tangga.

Tujuan dari program ini adalah untuk memberikan informasi pada masyarakat luas tentang bahaya limbah plastik terhadap lingkungan. Untuk mengurangi limbah plastik tersebut perlu penanganan khusus, yaitu dengan memanfaatkannya menjadi produk kreatif berupa tas dompet dan kerajinan lainnya.

Dengan ketrampilan hidup yang dimiliki oleh ibu-ibu di RT 08 dan RT 10 diharapkan dapat menambah kegiatan dan dapat menambah income keluarga. Kegiatan tersebut dapat dilakukan pada waktu luang sehingga waktu yang dimiliki dapat dimanfaatkan secara maksimal.

\section{METODE PELAKSANAAN}

Metode pelaksanaan program sebagaimana terurai pada bagan berikut ini :

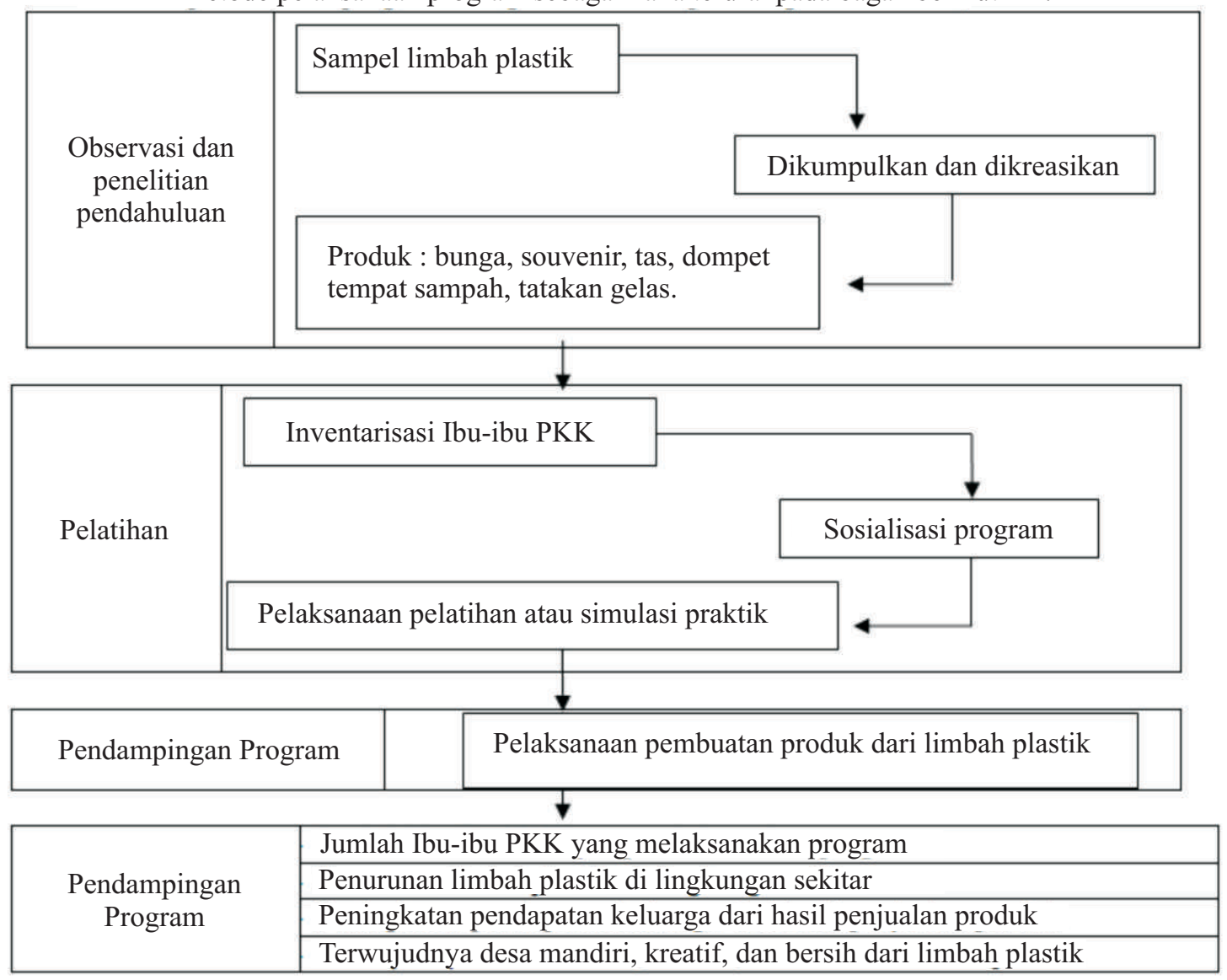

\section{HASIL DAN PEMBAHASAN}

Kegiatan dilaksanakan dalam dua kelompok kegiatan. Sosialisasi dilakukan untuk mengenalkan materi dan memulai mengumpulkan bahan. Pelaksanaan kegiatan dilakukan melalui pelatihan-pelatihan yang terjadwal secara rutin dengan mengacu pada materi-materi pelatihan yang telah diberikan dan capaian produk pada pertemuan berikutnya. Semua mitra atau peserta pelatihan menyambut positif dan sangat mendukung adanya program Ibm ini. Apalagi jenis kegiatan-kegiatan yang telah dilakukan tersebut sangat berdampak positif pada kehidupan mereka yaitu, lingkungan rumah menjadi bersih karena selama ini sampah tas kresek adalah sampah yang terbesar dihasilkan oleh rumah tangga bahkan ada slogan tiada hari tanpa tas kresek dan tiada rumah tanpa tas kresek, dampak berikutnya adalah waktu luang ibu-ibu rumah tangga menjadi lebih berharga tetap beraktivitas dan dapat dilakukan oleh siapa saja anak-anak maupun orang tua, selain itu yang sangat memotivasi adalah adanya produk tambahan di rumah mereka yang didapat tanpa membeli bahkan bisa dijadikan sebagai nilai tambah bagi keluarga utamanya warga Rt 8 dan RT 10 Desa Grobogan Kec. Jiwan Kabupaten Madiun.

Sementara itu kendala yang ditemukan antara lain : dibutuhkan waktu yang lama untuk mengumpulkan bahan baku yang senada, kebiasaan warga yang pekerja kasar dalam hal ini diladang atau di sawah, serta suasana penyuluhan yang ramai oleh anak kecil karena 
sebagain besar ibu-ibu rumah tangga tersebut datang ke tempat penyuluhan dengan putra-putri mereka yang masih kecil. Akhirnya untuk mengatasi kendala tersebut adalah diadakan koordinasi warna tas kresek terhadap warga yang punya toko dan utamanya warga yang punya hajatan seperti kenduri dan lain sebagainya. Kemudian untuk mengubah kebiasaan ini memang sulit karena mereka terbiasa kerja kasar kemudian harus merajut yang merupakan pekerjaan berjenis halus menurut mereka. Yang terjadi kemudian adalah sebagaian mereka memilih menyediakan bahan baku berupa benang kresek daripada merajut. Tetapi ada beberapa ibu rumah tangga yang mulai mahir dalam merajut dan hasilnya lumayan bagus dan halus.

Berawal dari keterbatasan bahan baku, tim melebarkan bahan baku dengan memilih limbah plastik kopi untuk dijadikan bahan baku membuat tas dan dompet. Respon lebih bagus dari sebelumnya karena teknik pembuatan produk lebih mudah dan lebih sederhana, yaitu dengan menganyam potongan-potongan limbah plastik yang telah dipilih berdasarkan corak tertentu yang ada didalam limbah tersebut. Dengan semakin berkembangnya produk yang dibuat semakin membuat ibu-ibu lebih bersemangat dalam latihan dan limbah disekitar lingkungan tersebut terkurangi dengan adanya kegiatan ini. Ibu-ibu lebih selektif lagi dalam memilah milah sampah yang bisa didaur ulang dan tidak.

Diharapkan ibu-ibu tersebut nanti dapat meneruskan program ini jika program pendampingan ini telah usai. Sementara itu untuk suasana ramai karena anak-anak cara mensiasatinya adalah dengan memberikan atau menyediakan makanan kecil yang disukai anakanak.

\section{KESIMPULAN}

Berdasarkan evaluasi terhadap pelaksanaan program Ibm tersebut dapat dismpulkan bahwa:

a. Harus ada keberlanjutan dari program tersebut karena program ini mempunyai dampak positif bagi lingkungan dan ekonomi warga. Apalagi warga menyambutnya dengan antusias.

b. Pembuatan produk kreatif dari limbah tas kresek ini adalah salah satu cara dari berbagai macam cara yang bisa digunakan warga untuk mengatasi sampah rumah tangga.

c. Usaha kreatif dapat dilakukan untuk mengatasi masalah lingkungan yang berupa sampah plastik dan dapat menambah income rumah tangga.

\section{REFERENSI}

Denik Restya Rini, 2013, Clutch Bag Crochet, Tiara Aksara, Surabaya.

Endah R.A. 2014. Inspirasi dari Kantong Plastik, Tiara Aksara Surabaya.

Tata Phang. 2012. Pernak-Pernik Rajutan, Kriya Pustaka, Jakarta.

Wina Adam. 2012. Crochet Unik \& Apik. Kriya Pustakan, Jakarta.

Yohana, 2012, Rajut untuk Alasan Peralatan Dapur, Tiara Aksara, Surabaya. 